\title{
Antispasmodic, bronchodilator, vasorelaxant and cardiosuppressant effects of Buxus papillosa
}

\author{
Arif-ullah Khan ${ }^{1 *}$, Shamsher Ali $^{2}$, Anwarul-Hassan Gilani ${ }^{3,4^{*}}$, Manzoor Ahmed ${ }^{5}$ and Muhammad lqbal Choudhary ${ }^{6}$
}

\begin{abstract}
Background: The present research was carried out to investigate pharmacological properties of Buxus papillosa C.K. Schneid. (Buxaceae).

Methods: Buxus papillosa extracts of leaves (BpL), stem (BpS), roots (BpR) and BpL fractions: hexane (BpL-H), aqueous (BpL-A) also plant constituent, cyclomicrobuxine effect were studied in jejunum, atria, aorta and tracheal preparations from rabbit and guine-peg.

Results: $\mathrm{Ca}^{++}$antagonistic effect of BpS, BpR, BpL-H, BpL-A and cyclomicrobuxine were conclusively suggested, when spontaneous contractions of rabbit jejunal preparation was relaxed along with subsequent relaxation of potassium chloride $(80 \mathrm{mM})$ induced contractions. $\mathrm{Ca}^{++}$antagonistic effect was further confirmed, when a prominent right shift like that of verapamil was observed in $\mathrm{Ca}^{++}$concentration-response curves, drawn in a tissue pretreated with BpL (0.3-1.0 mg/mL). In rabbit tracheal tissues BpL, BpS, BpR, BpL-H and BpL-A produced a prominent relaxation in contractions induced by potassium chloride $(80 \mathrm{mM})$ and carbachol $(1 \mu \mathrm{m})$. When tested in rabbit aortic rings, BpL, BpS, BpR, BpL-H and BpL-A showed concentration-dependent (0.1-3.0 mg/mL) vasorelaxant effect against phenylephrine $(1 \mu \mathrm{M})$ and high $\mathrm{K}^{+}$-induced contractions. In isolated guinea-pig right atria, $\mathrm{BpL}, \mathrm{BpS}$, BpR, BpL-H and BpL-A suppressed atrial force of spontaneous contractions, with BpL-A being most potent.
\end{abstract}

Conclusions: Our results reveal that Buxus papillosa possesses gut, airways and cardiovascular inhibitory actions.

Keywords: Buxus papillosa, Antispasmodic, Bronchodilator, Vasodilator, Cardio-depressant, $\mathrm{Ca}^{++}$antagonist

\section{Background}

The genus Buxus comprises of approximately 70 species commonly called boxwood,which are native to Europe, Asia, Africa, Madagascar, America, Maxico, Caribbean, Cuba and China. Buxus papillosa C.K. Schneid, locally known as shamshad is dense, compact ever green shrub of 0.5-1.0 m height, belonging to Buxaceae family. In Pakistan, it is distributed throughout Himalaya regions and northern areas. Traditionally used to cure malaria, rheumatism, skin diseases, headache, also considered useful as antidiarrheal, antisecretorycardiotonic and

\footnotetext{
* Correspondence: arif.ullah@riphah.edu.pk; arifullahkhan979@hotmail.com; anwar.gilani@aku.edu; anwarhgilani@yahoo.com

'Department of Pharmacology, Riphah Institute of Pharmaceutical Sciences, Riphah International University, Islamabad, Pakistan

${ }^{3}$ Department of Biological and Biomedical Sciences, The Aga Khan University Medical College, Karachi 74800, Pakistan

Full list of author information is available at the end of the article
}

neurotonicagent [1]. It has been widelyevaluated to unfold its phytochemical profile. Buxuspappilosa is known to containcyclobuxupaline- $C$, cyclopapilosine- $D$, (+)-buxamine- $C$, desoxy-16-buxidienine [2], harappamine [3], moenjodaramine [4], papilicine [5], buxaminolG,cyclobuxaviridine, papilamine, papilinie [6-8], (+) -buxabenzamidienine, $(+)-16 \alpha$-acetoxybuxabenzamidienine, (+)-buxotrienine, (-)-buxanoldine, $(+)$-buxanaldinine [9], $\mathrm{N}$-formylcyclomicrobuxeine [10], (+)-buxabenzamidine, $(+)$-homobuxaquamarine, $(+)$-norcyclomicrobuxeine, $(+)$ buxupapine, (+)-Nb-norbuxupapine, cyclobuxoviridine [11], (+)-N-acetyl-N-demethylcyclomicrobuxeine, buxaminone [12, 13], (E)-cyclobuxaphylamine, (Z)-cyclobuxaphylamine, (+)-formylharappamine, (+)-N-formylpapalicine $[14,15]$, buxatenone, cyclobuxaviramine [16], buxapapilinine [17], (+)papillotrienine, (+)-N(b)-demethylpapillotrienine, $(+)-\mathrm{N}(\mathrm{b})$-demethylharappamine [18], buxapapillosine 
[19], 11-hydroxybucatenone and buxahejrine [20]. Three alkaloids (Triterpenoids): buxahejramine [(20S) 20-dimethylamino- 2'-hydroxy- 3beta-methyl-3'-methylpentanoylamino-9, 10-seco-buxa-9(11), 10(19)-dien31-ol], buxakashmiramine [(20S)- 20-dimethylamino4',6'- dimethoxy-5' - hydroxybenzoylamino- 3betamethyl-buxan-31-ol] and buxakashmiramine [(20S)20-dimethylamino-4', 6' - dimethoxy-5' - hydroxybenzoylamino- 3beta-methyl-buxan-31-ol] isolated from leaves of Buxuspapillosa are reported to possess acetylcholinesteraseand butyrylcholinesterase inhibitory properties [21]. Buxus papillosa showed acaricidal effect in larval immersion test [22].

Despite of diverse ethnomedicinal and phytochemical profile of this plant, extensive pharmacological screening has not been performed yet. In our previous studies, we observed that several medicinal plants, which exhibits similar nature of constituents (as present in Buxus papillosa) with therapeutic potential in treating ailments of gut, airways, heart and vascular hyperactivity, usually possess spasmolytic properties, occurred via either alone or combinations of different pharmacodynamics mechanisms, like inhibition of $\mathrm{Ca}^{++}$ingress and phosphodiesterase enzyme(s), antagonism of muscarinic receptors and potassium channel activation [23-27]. In the current investigation, the gastrointestinal, respiratory and cardiovascular inhibitory actions of Buxus papillosa leaves, stem and roots extracts are reported, also further the leaves extract various fractions: hexane and aqueous. The pure compound, isolated from leaves ofthe plant, cyclomicrobuxine showed antispasmolytic effect.

\section{Methods}

\section{Plant material extraction, fractionation and isolation}

Buxus papillosa was collected from Malam Jabba, Swat, Khyber Pakhtunkhwa (KPK), Pakistan during JulyAugust, 2002. Specimen was authenticated by Mahboob-ur-Rahman, taxonomist at Department of Botany, Government Post Graduate Jahanzeb College, Saidu Sharif, Swat, KPK. Voucher bearing number BP-129 was obtained and specimen submitted to herbarium at same college for future record. Plant material was dried under shade for 20-25days and separated into leaves $(44.7 \mathrm{Kg})$, stem $(14.5 \mathrm{Kg})$ and roots $(42 \mathrm{Kg})$ parts. All three parts were individually ground and macerated in aqueous methanol (70\%) for period of 7 days at room temperature [28, 29]. Mixtures were then filtered and concentrated under reduced pressure to yieldBuxuspappilosaextracts of leaves $(\mathrm{BpL})$, stem $(\mathrm{BpS})$ and roots $(\mathrm{BpR})$. For defatting the extract of leaves, distilled water was added and mixed with it thoroughly, followed by mixing with $n$-hex in a separating funnel. When two distinct layers were formed the $n$-hexane portion was separated out and the whole process was repeated thrice. Finally, the entire collected $n$-hexane portion was concentrated in rotary to receive (BpL-A). Similarly for obtaining Aqueous fraction (BpL-A), the lower layer in the separating funnel was evaporated in separate Petri dish. Cyclomicrobuxine (Fig. 1), a known compound $[30,31]$ was isolated from hexane fraction of Buxuspapillosaleaves extract, using silica gel column chromatography technique [32].

\section{Chemicals}

Acetylcholine chloride (ACh), verapamil, isoprenaline hydrochloride, carbachol $(\mathrm{CCh})$ and phenylephrine hydrochloride (PE) were purchased from Sigma Chemicals Co. MO, USA. Various kinds of chemical were used for the preparation of physiological solutions like: magnesium sulfate,sodium dihydrogen phosphate, calcium chloride, glucose, sodium bicarbonate ,magnesium chloride and potassium dihydrogen phosphate were purchased from Merck, Germany, while potassium chloride $(\mathrm{KCl})$, ethylenediamine tetraacetic acid from Sigma Chemical Co, USA. Similarly Sodium chloride was purchased from BDH Laboratory, England. Analytical grade chemical were used for performing the experiments.

\section{Animals}

For conducting this study Adult guinea-pigs (500$550 \mathrm{~g})$ and rabbits $(1-1.2 \mathrm{~kg})$ were collected from the Animal House of Aga Khan University. Standard diet and water were given to all of them under maintained temperature of $23-25{ }^{\circ} \mathrm{C}$. Rabbits and guinea-pigs were starved for $24 \mathrm{~h}$ before starting the experiments

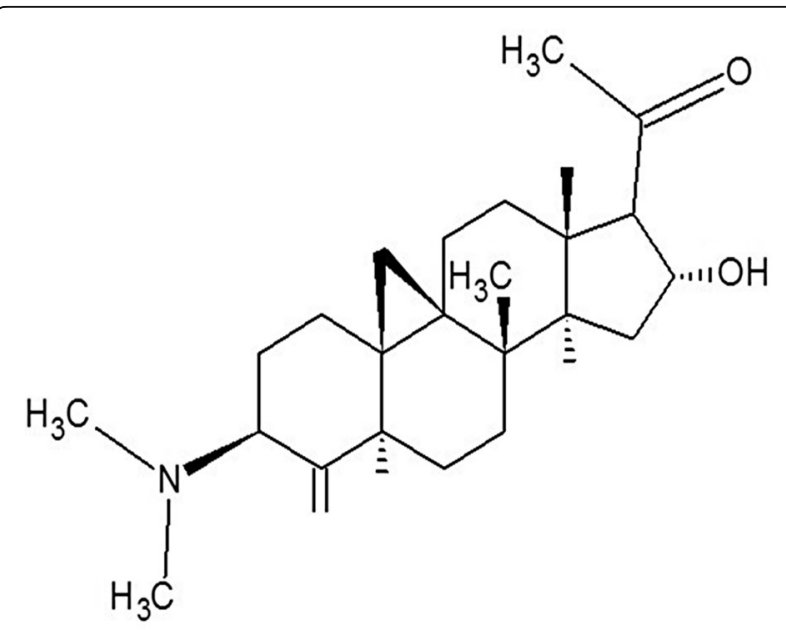

Fig. 1 Chemical structure of cyclomicrobuxine, pure compound isolated from leaves of Buxus papillosa 
and were scarified by cervical dislocation to obtain the target tissue. Studies conducted completely comply with the protocols of the Institute of Laboratory Animal Resources, Commission on Life Sciences, National Research Council [33], approved by Research and Ethics Committee (Ref\#: REC/RIPS/2016/005), Riphah Institute of Pharmaceutical Sciences.

\section{Rabbit jejunum}

Three segments of jejunum, each $2 \mathrm{~cm}$ were dissected out from rabbit abdomen. Single segment of jejunum was suspended via a thread in a tissue bath continuously supplied with carbogen. Tyrode's solution used is composed of $(\mathrm{mM}): \mathrm{NaHCO}_{3}$ 11.90, glucose 5.55, $\mathrm{CaCl}_{2}$ 1.8, $\mathrm{KCl} 2.68, \mathrm{MgCl}_{2} 1.05, \mathrm{NaCl} 136.9$ and $\mathrm{NaH}_{2} \mathrm{PO}_{4}$ 0.42. Bioscience transducers and Harvard oscillograph was used for recording intestinal responses isotonically. Before addition of drug, tissue was freely permitted to equilibrate for $30 \mathrm{~min}$. The tissue was then completely stabilized by applying submaximal concentration of $0.3 \mu \mathrm{M}$ Ach after every three minutes, unless uniform responses were achieved. Spontaneous contractions are exhibited in such environment, thereby providing an opportunity to directly check the spasmolytic effect, without prior applying of agonist [34]. Depolarization of jejunal preparations was done by high $\mathrm{K}^{+}(80 \mathrm{mM})$, so that $\mathrm{Ca}^{++}$channel blockade (CCB) activity can be determined according to procedure of Gilani et al. [35]. After sustained contractions produced by high $\mathrm{K}^{+}$in jejunal tissue, test substance was applied for producing inhibitory effect. For confirming the $\mathrm{Ca}^{++}$antagonistic activity, the jejunal tissue was stabilized in normal and $\mathrm{Ca}^{++}$-free Tyrode's solutions. After 30 min the tissue was washed with by $\mathrm{K}^{+}$-rich and $\mathrm{Ca}$ ${ }^{++}$-free Tyrode's solution. CRCs of $\mathrm{Ca}^{++}$were drawn and recorded. The treated tissue was applied with test substance and incubated for one hour, followed by reconstruction of CRCs of $\mathrm{Ca}^{++}$to explore the possible CCB effect. Different concentration of test substance was applied on treated tissue and CRCs of $\mathrm{Ca}^{++}$were constructed.

\section{Rabbit trachea}

Soon after dissection of trachea, approximately 2$3 \mathrm{~mm}$ wide tracheal tube rings were cut down, each ring containing two cartilages were opened further by longitudinal incision to prepare tracheal strips [36]. Single tracheal strip was suspended in tissue bath $(20 \mathrm{~mL})$ containing standard physiological kreb's solution, continuously supplied with carbogen and maintained at $37{ }^{\circ} \mathrm{C}(\mathrm{pH}$ 7.4). Kreb's solution used for this experiment was composed of $(\mathrm{mM})$ glucose: 11.7, $\mathrm{KH}_{2} \mathrm{PO}_{4}: 1.2, \mathrm{NaCl}: 118.2, \mathrm{CaCl}_{2}: 2.5, \mathrm{MgSO}_{4} \cdot 7 \mathrm{H}_{2} \mathrm{O}$ :
1.2, NaHCO3: 25.0, KCl: 4.7. Strips were permitted to equilibrate for almost $1 \mathrm{~h}$ before applying any test substance. Throughout experiment tracheal strips were applied with tension of $1 \mathrm{~g}$. After the application of spasmogens like $\mathrm{CCh}$ and/or high $\mathrm{K}^{+}$, when sustained contractions were achieved then spasmolytic effect of drug was tested by its addition in cumulative manner. Grass model 7 Polygraph (USA) was used for recording the isometric responses of tracheal strips.

\section{Rabbit aorta}

Krebs solution in a $20 \mathrm{~mL}$ tissue bath was used for conducting the experiment; aortic rings were mounted in it, where bath environment was maintained at $37{ }^{\circ} \mathrm{C}$ along with continuous supply of carbogen. Before studying the effect of drug, aortic ring was stabilized by applying tension of $2 \mathrm{~g}$. After the application of PE $(1 \mu \mathrm{M})$ and $\mathrm{K}^{+}$ $(80 \mathrm{mM})$, vasorelaxant effect of testing material was assessed [37]. Force-displacement transducer and Grass model 7 Polygraph were used for recording changes in isometric tension of aortic rings.

\section{Guinea-pig atria}

Right atrium was isolated and suspended through wire gauze in $20 \mathrm{~mL}$ tissue bath containing Krebs solute, maintained at $32{ }^{\circ} \mathrm{C}$ continuously supplied with carbogen gas. Due to presence of natural pacemaker in the atrium, Spontaneous beating was observed under the resting tension of $1 \mathrm{~g}$ [38]. After $45 \mathrm{~min}$ of equilibrium period, control response curves of $1 \mu \mathrm{M}$, isoprenaline and $\mathrm{ACh}$ were recorded. Force-displacement transducer and Grass model 7 Polygraph were used for recording changes in isometric tension of atria.

\section{Statistical analysis}

Recorded data obtained is shown as mean \pm standard error of mean (SEM, $\mathrm{n}=$ number of experiment) and median effective concentrations $\left(\mathrm{EC}_{50}\right)$ with $95 \%$ confidence intervals (CI). GraphPad program (USA) was used by applying non-linear regression for analyzing Concentration-response curves.

\section{Results}

\section{Effect on jejunum}

Isolated jejunal preparations spontaneous contractions and induced contractions of high $\mathrm{K}^{+}(80 \mathrm{mM})$ were concentration dependently inhibited by $\mathrm{BpL}, \mathrm{BpS}, \mathrm{BpR}$, $\mathrm{BpL}-\mathrm{H}$ and BpL-A with respective $\mathrm{EC}_{50}$ values of 0.63 $(0.46-0.86, n=5,95 \% \mathrm{CI})$ and $0.80(0.71-0.84, n=6)$, $1.02(0.70-1.50, n=5)$ and $1.20(0.85-1.65, n=4), 1.25$ $(0.99-1.65, n=6)$ and $1.23(0.94-1.54, n=5), 0.55(0.42-$ $0.74, n=3)$ and $0.73(0.62-0.89, n=3), 0.014(0.008-$ $0.02, n=6)$ and $0.008 \mathrm{mg} / \mathrm{mL}(0.001-0.04, n=4)$ as shown in Figs. 2, 3 and Table 1. Cyclomicrobuxine 


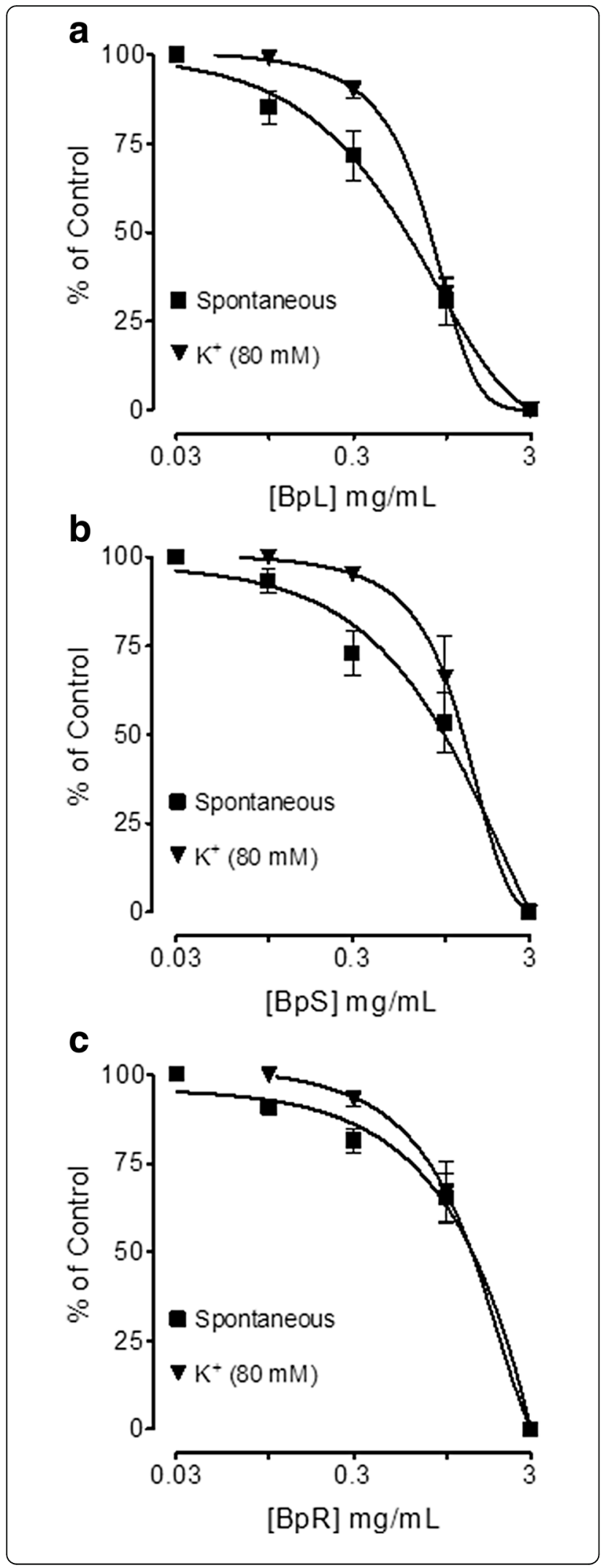

Fig. 2 Concentration-dependent inhibitory effect of Buxus papillosa different parts extracts: a leaves (BpL), b stem (BpS) and $\mathbf{c}$ roots $(\mathrm{BpR})$ on spontaneous and high $\mathrm{K}^{+}$-induced contractions in isolated rabbit jejunum preparations. Values shown are mean \pm SEM, $n=4-6$
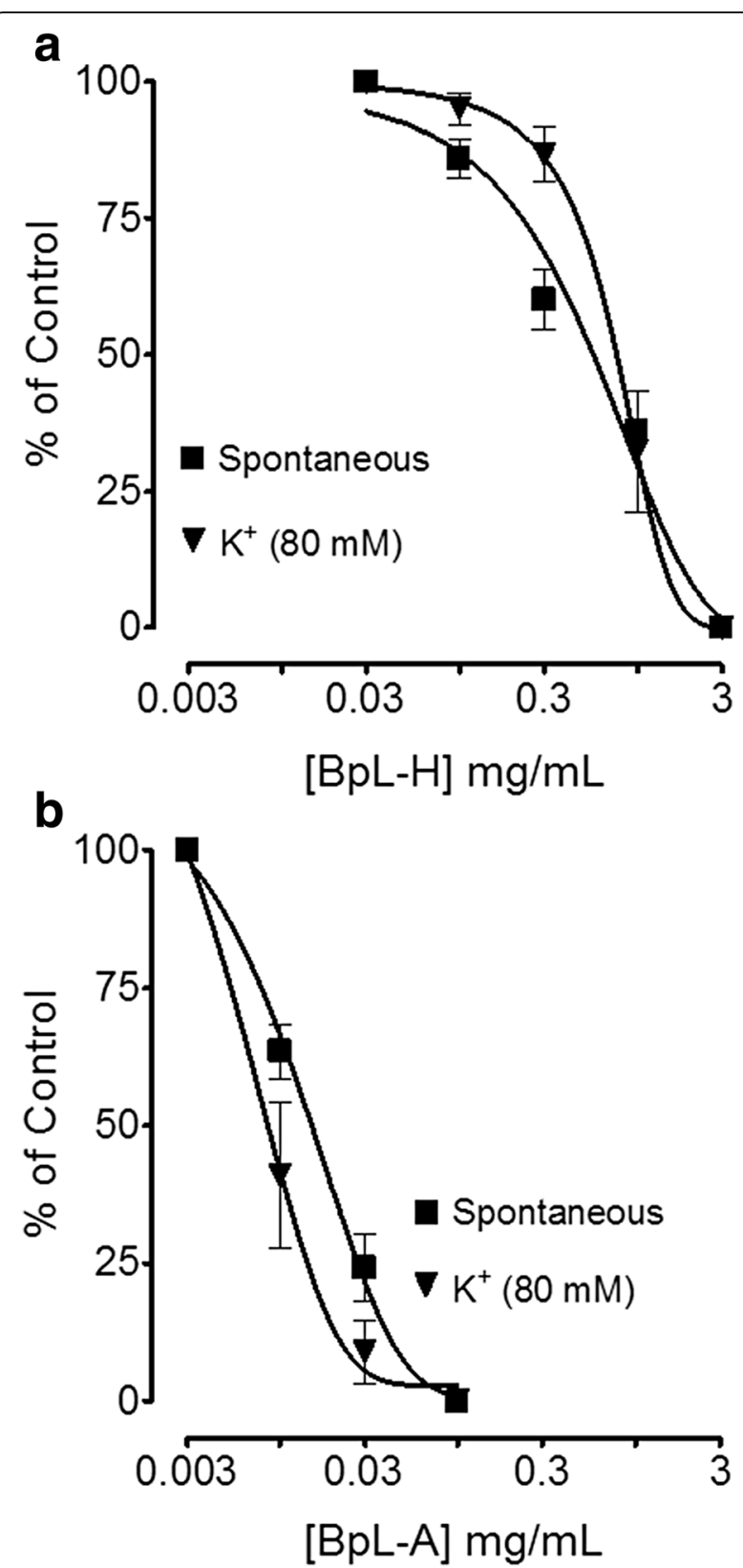

Fig. 3 Concentration-dependent inhibitory effect of Buxus papillosa leaves extract fractions: a hexane (BpL-H) and $\mathbf{b}$ aqueous (BpL-A) on spontaneous and high $\mathrm{K}^{+}$-induced contractions in isolated rabbit jejunum preparations. Values shown are mean \pm SEM, $n=3-6$ 
Table 1 Comparative median effective concentration ( $\left.\mathrm{EC}_{50}\right)$ values of the Buxus papillosa different parts extracts: leaves (BpL), stem $(\mathrm{BpS})$ and roots $(\mathrm{BpR})$ also leaves extract fractions: hexane $(\mathrm{BpL}-\mathrm{H})$ and aqueous $(\mathrm{BpL}-\mathrm{A})$ against various parameters in different isolated tissue preparations of rabbit and guinea-pig (atria)

\begin{tabular}{|c|c|c|c|c|c|c|c|}
\hline \multirow[t]{2}{*}{ Sample } & \multicolumn{2}{|l|}{ Jejunum } & \multicolumn{2}{|l|}{ Trachea } & \multicolumn{2}{|l|}{ Aorta } & \multirow{2}{*}{$\begin{array}{l}\text { Atria } \\
\text { Atrial force }\end{array}$} \\
\hline & Spontaneous & $\mathrm{K}^{+}(80 \mathrm{mM})$ & $\overline{C C h}(1 \mu \mathrm{M})$ & $\mathrm{K}^{+}(80 \mathrm{mM})$ & $\overline{P E}(1 \mu \mathrm{M})$ & $\mathrm{K}^{+}(80 \mathrm{mM})$ & \\
\hline $\mathrm{BpL}$ & 0.63 & 0.80 & 0.28 & 0.28 & 0.75 & 0.50 & 4.0 \\
\hline BpS & 1.02 & 1.20 & 0.26 & 0.85 & 0.98 & 1.3 & 1.80 \\
\hline $\mathrm{BpR}$ & 1.25 & 1.23 & 0.10 & 0.34 & 1.25 & 0.95 & 3.60 \\
\hline BpL-H & 0.55 & 0.73 & 0.25 & 0.31 & 0.98 & 1.1 & 1.50 \\
\hline BpL-A & 0.014 & 0.008 & 0.12 & 0.10 & 0.40 & 0.37 & 0.30 \\
\hline
\end{tabular}

relaxed spontaneous contractions and induced contractions of high $\mathrm{K}^{+}(80 \mathrm{mM})$ with $\mathrm{EC}_{50}$ values of 21.0 $(10.1-30.3, n=2)$ and $65.1 \mu \mathrm{g} / \mathrm{mL}(50.1-70.6, n=2)$ respectively (Fig. 4a). Verapamil relaxed spontaneous and potassium chloride $(80 \mathrm{mM})$-induced contractions (Fig. 4b) with respective $\mathrm{EC}_{50}$ values of 0.09 (0.07-0.11, $n=4)$ and $0.013 \mu \mathrm{M}(0.01-0.02, n=4)$. BpL $(0.3-$ $1.0 \mathrm{mg} / \mathrm{mL}$ ) shifted $\mathrm{Ca}^{++}$CRCs to the right (Fig. 5a), like that caused by verapamil (Fig. 5b).

\section{Effect on trachea}

Pre-contracted, tracheal preparations with CCh $(1 \mu \mathrm{M})$ and $\mathrm{K}^{+}(80 \mathrm{mM})$ were concentration-dependently relaxed by $\mathrm{BpL}, \mathrm{BpS}, \mathrm{BpR}, \mathrm{BpL}-\mathrm{H}$ and $\mathrm{BpL}-\mathrm{A}$ with $\mathrm{EC}_{50}$ values of $0.28(0.24-0.33, n=5)$ and $0.28(0.22-0.36, n=$ 4), $0.26(0.13-0.41, n=4)$ and $0.85(0.70-0.94, n=4)$, $0.10(0.07-0.13, n=4)$ and $0.34(0.23-0.59, n=4), 0.25$ $(0.16-0.33, n=2)$ and $0.31(0.27-0.37, n=2), 0.12(0.08-$ $0.19, n=2)$ and $0.10 \mathrm{mg} / \mathrm{mL}(0.04-0.25, n=3)$ respectively (Figs. 6, 7 and Table 1).

\section{Effect on aorta}

When tested against induced contractions of potassium chloride $(80 \mathrm{mM})$ and PE $(1 \mu \mathrm{M}), \mathrm{BpL}, \mathrm{BpS}, \mathrm{BpR}, \mathrm{BpL}-$ $\mathrm{H}$ and BpL-A exhibited vasorelaxant effect (Figs. 8, 9 and Table 1) with respective $\mathrm{EC}_{50}$ values of $0.75(0.50-$ $1.1, n=4)$ and $0.50(0.40-0.60, n=5), 0.98(0.70-1.41, n$ $=4)$ and $1.3(1.0-1.50, n=4), 1.25(0.91-1.61, n=4)$ and $0.95(0.81-1.11, n=4), 0.98(0.96-1.0, n=3)$ and 1.1 $(0.92-1.3, n=2), 0.40(0.23-0.71, n=2)$ and $0.37 \mathrm{mg} / \mathrm{mL}$ $(0.16-0.89, n=2)$.

\section{Effect on atria}

BpL, BpS, BpR, BpL-H and BpL-A exerted concentration-dependent inhibitory effect on spontaneously beating atrial force of contractions with $\mathrm{EC}_{50}$ values of $4.0(3.0-5.5, n=3), 1.80(0.25-6.30, n=3), 3.60$ $(3.50-4.0, n=3), 1.50(0.44-4.0, n=3)$ and $0.30 \mathrm{mg} / \mathrm{mL}$ $(0.28-0.35, n=3)$ respectively (Fig. 10 and Table 1$)$.

\section{Discussion}

When tested in jejunum preparations, Buxus papillosa different parts extracts and fractions exhibited antispasmodic effect through inhibition of spontaneous contractions. Antispasmodic effect of aqueous fraction was 45 and 40 times more potent as compared to parent leaves extract and hexane fraction respectively. The plant isolated compound, cyclomicrobuxine also relaxed jejunum spontaneous contractions. When the level of free $\left[\mathrm{Ca}^{++}\right]$ increases the rudiments responsible for contractions in the cells get activated, leading to ultimate contraction of smooth muscles $[39,40]$. Intracellular calcium level either increases through voltage dependent L-type $\mathrm{Ca}^{++}$ channels (VDCs) or through discharge from sarcoplasmic reticulum internal stores. Regulation of Spontaneous intestinal contractions is primarily attributed to intermittent depolarization and action potential appears at the height of depolarization when rapid influx of $\mathrm{Ca}^{++}$via VDCs takes place [41]. So the spontaneous intestinal contractions may be inhibited by the plant extract due to interruption with $\mathrm{Ca}^{++}$release inside the cell or $\mathrm{Ca}^{++}$ influx through VDCs.

Previous studies strongly suggest that plant extracts usually mediate relaxation through blockade of $\mathrm{Ca}^{++}$ channels [42-46]. To check out whether same mechanism is followed by this plant extract for achieving spasmolytic effect, Buxus papillosa test samples were screened against contractions induced by potassium chloride $(80 \mathrm{mM})$ which was fully inhibited, with Aqueous fraction being most potent. Plant bioactive constituent, cyclomicrobuxine also relaxed contractions induced by potassium chloride $(80 \mathrm{mM})$. It was observed that, cyclomicrobuxine was 30 and 12 times more potent respectively in comparison to plant extracts, against spontaneous and potassium chloride induced contractions. Verapamil, a standard $\mathrm{Ca}^{++}$channel blocker [47] also inhibited spontaneous contractions and contractions induced by potassium chloride $(80 \mathrm{mM})$ non-specifically. Smooth muscle contraction is induced by high concentration of $\mathrm{K}^{+}(>30 \mathrm{mM})$ via opening of VDCs, where it permits entrance of $\mathrm{Ca}^{++}$from outside the cell [48]. So, drug inhibiting potassium chloride $(80 \mathrm{mM})$ induced 


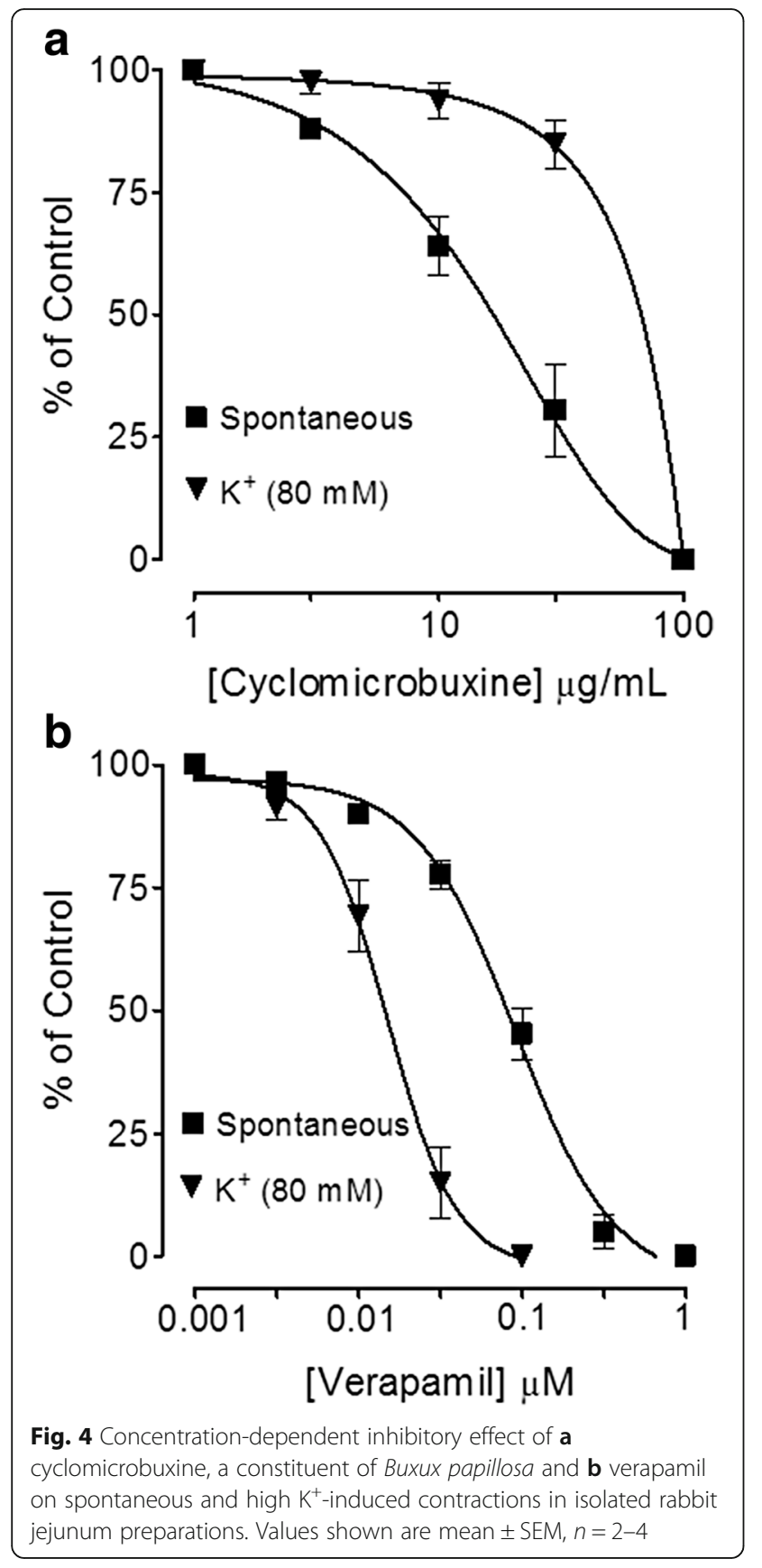

contractions is believed to be the inhibitor of $\mathrm{Ca}^{++}$influx [49]. When plant extract exhibited right shift in the $\mathrm{Ca}^{++}$ CRCs and suppressed the maximal response like that of a standard calcium antagonist; verapamil, the existence of $\mathrm{Ca}^{++}$antagonist effect strengthened. Concentrationdependent inhibition of slow entry of $\mathrm{Ca}^{++}$is one of the prominent and common features of calcium antagonists [50, 51]. Buxus papillosa has been medicinally used in gut hyper motility disorder and diarrhea. $\mathrm{Ca}^{++}$channel blockers are usually effective in this condition [52] and

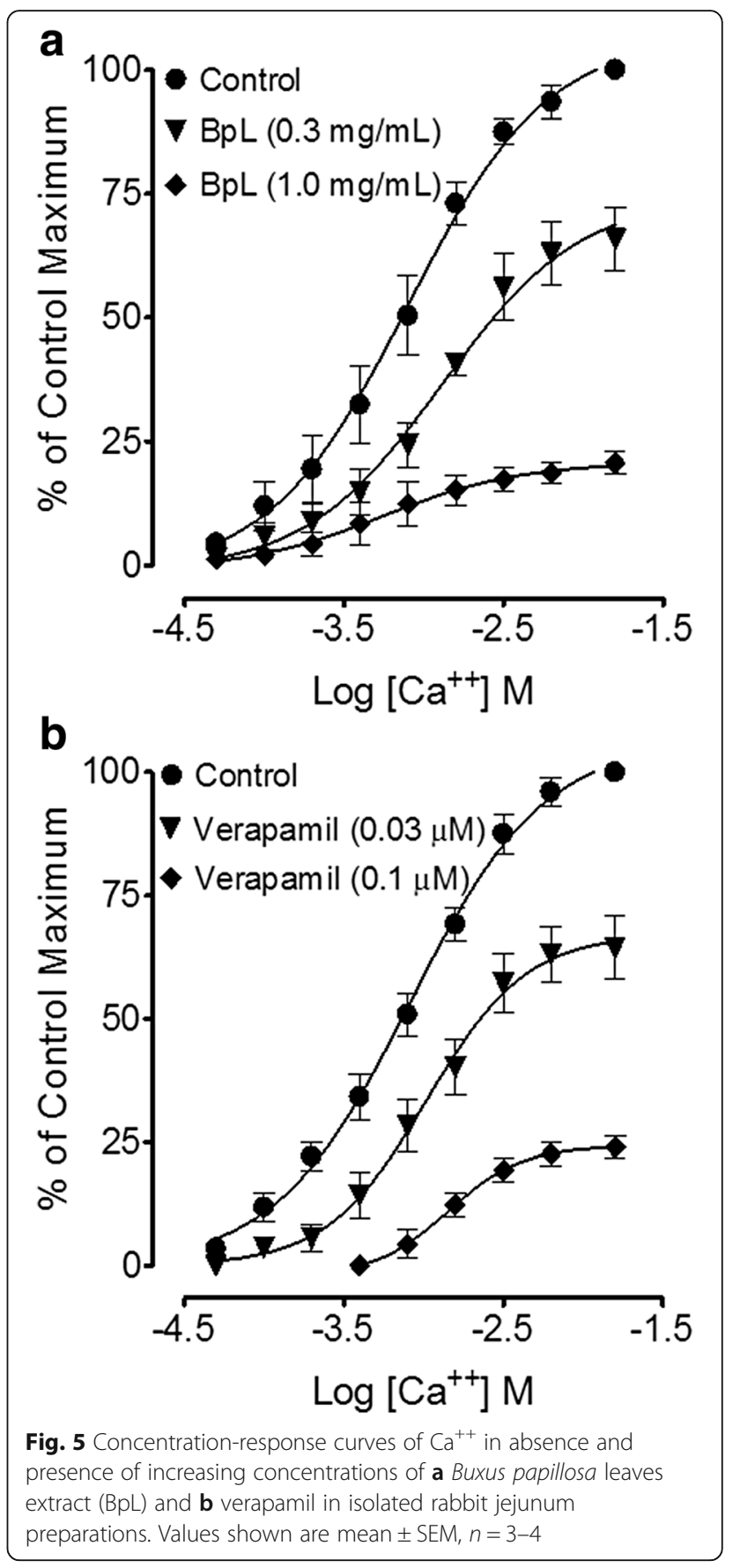

the observed CCB effect of this plant may clarify its potential in these diseases.

In trachea, Buxus papillosa test samples relaxed the contractions induced by high $\mathrm{K}^{+}$and $\mathrm{CCh}$, showing tracheo-relaxant effect. Smooth muscles contractions is produced by cholinergic agonist like $\mathrm{CCh}$ and high $\mathrm{K}^{+}$ via stimulation of muscarinic receptor and opening of $\mathrm{L}$ type $\mathrm{Ca}^{++}$channel respectively, finally enhancing $\mathrm{Ca}^{++}$ level inside the cell and bronco constriction as the 


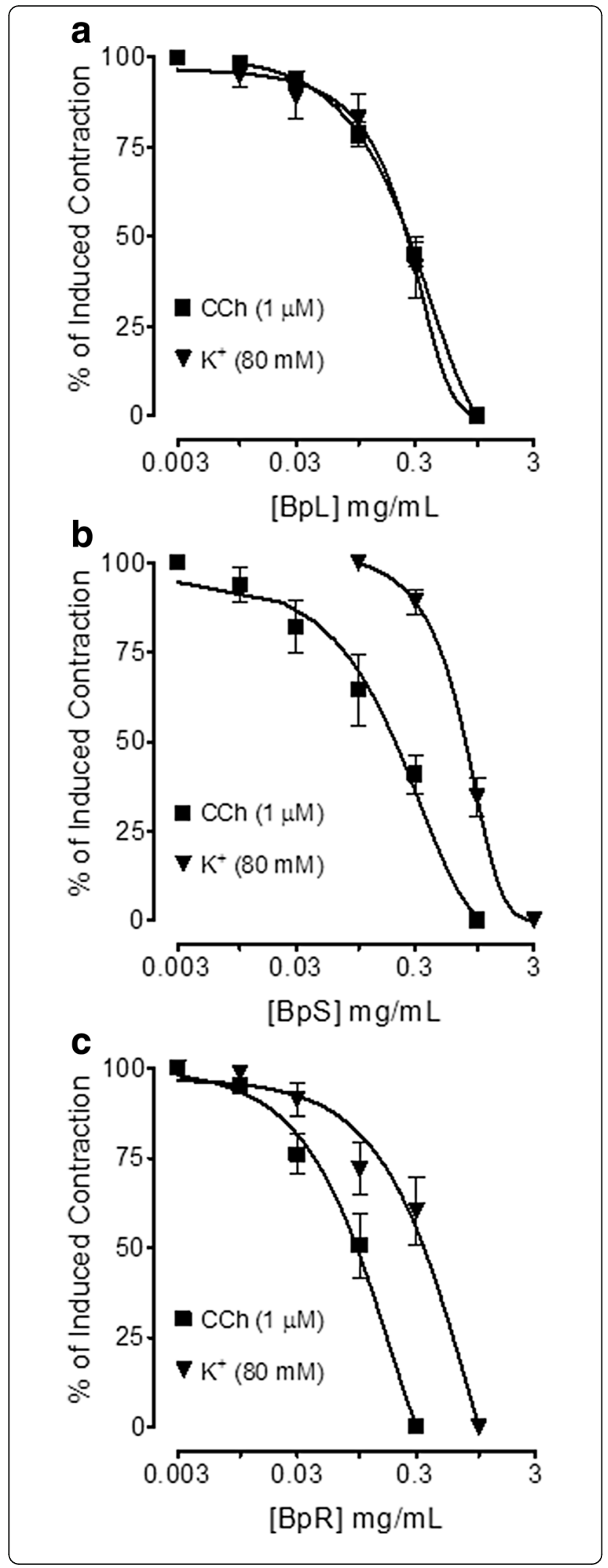

Fig. 6 Concentration-dependent inhibitory effect of Buxus papillosa different parts extracts: a leaves (BpL), b stem (BpS) and $\mathbf{c}$ roots (BpR) on carbachol (CCh) and high $\mathrm{K}^{+}$-induced contractions in isolated rabbit tracheal preparations. Values shown are mean \pm SEM, $n=4-5$
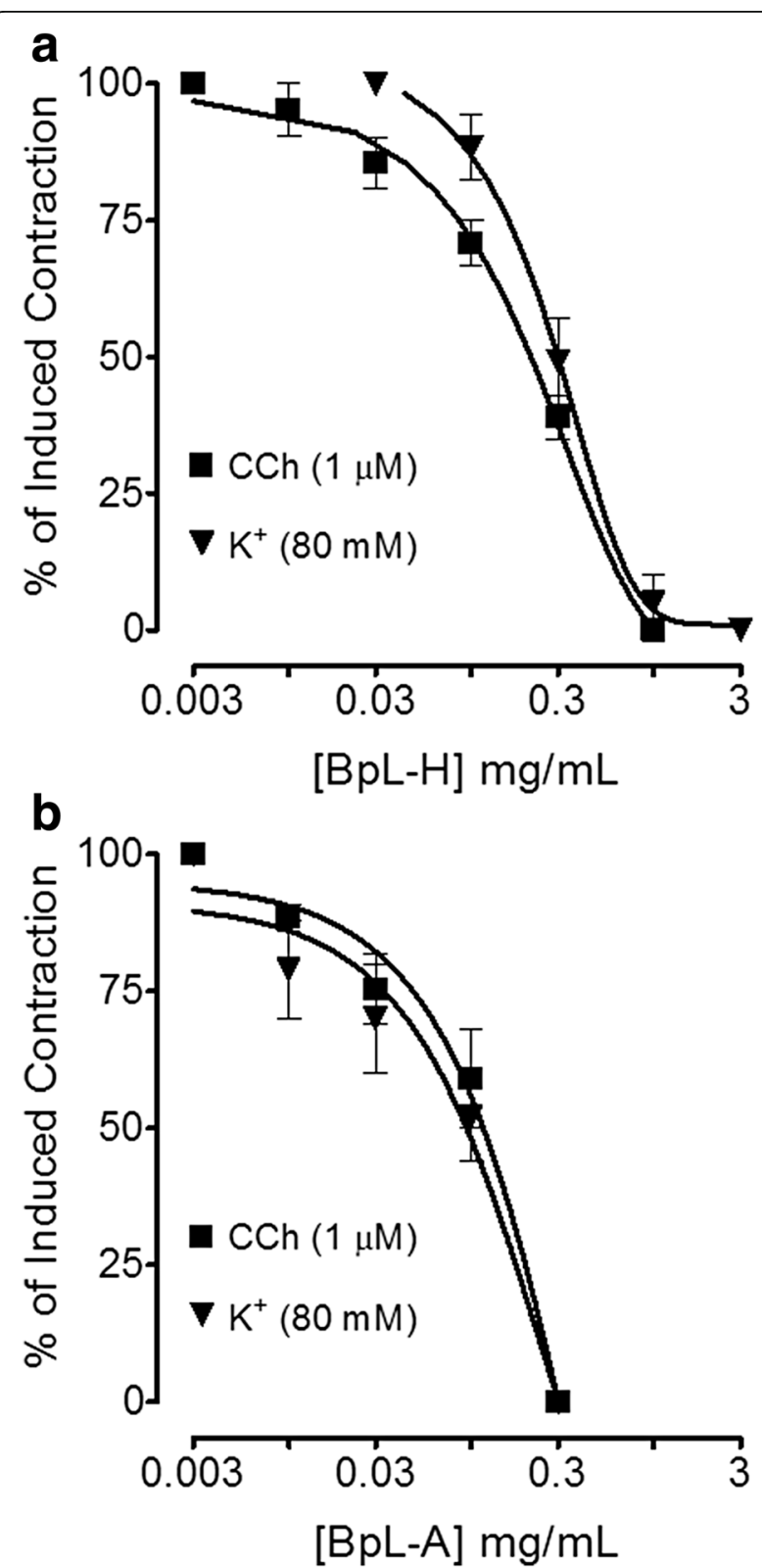

Fig. 7 Concentration-dependent inhibitory effect of Buxus papillosa leaves extract fractions: a hexane (BpL-H) and $\mathbf{b}$ aqueous (BpL-A) on carbachol (CCh) and high $\mathrm{K}^{+}$-induced contractions in isolated rabbit tracheal preparations. Values shown are mean \pm SEM, $n=2-3$ 


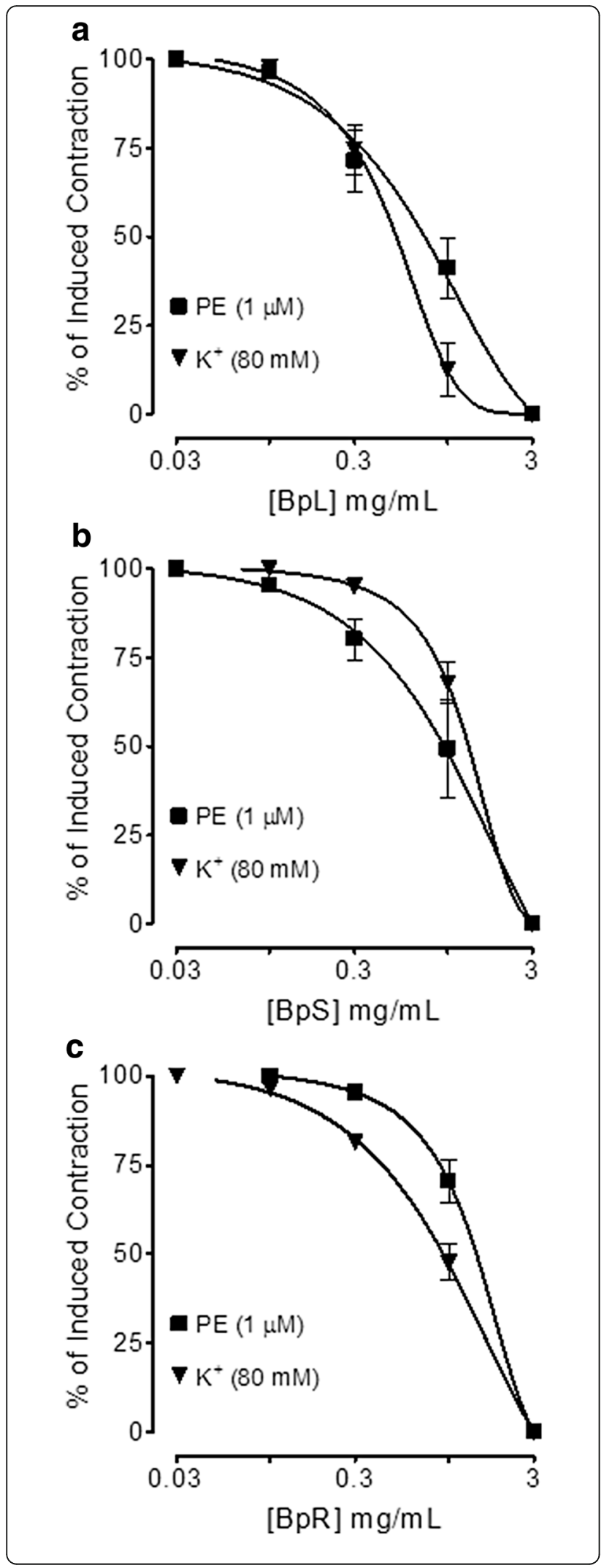

Fig. 8 Concentration-dependent inhibitory effect of Buxus papillosa different parts extracts: a leaves (BpL), b stem (BpS) and $\mathbf{c}$ roots $(\mathrm{BpR})$ on phenylephrine (PE) and high $\mathrm{K}^{+}$-induced contractions in isolated rabbit aortic preparations. Values shown are mean \pm SEM, $n=4-5$
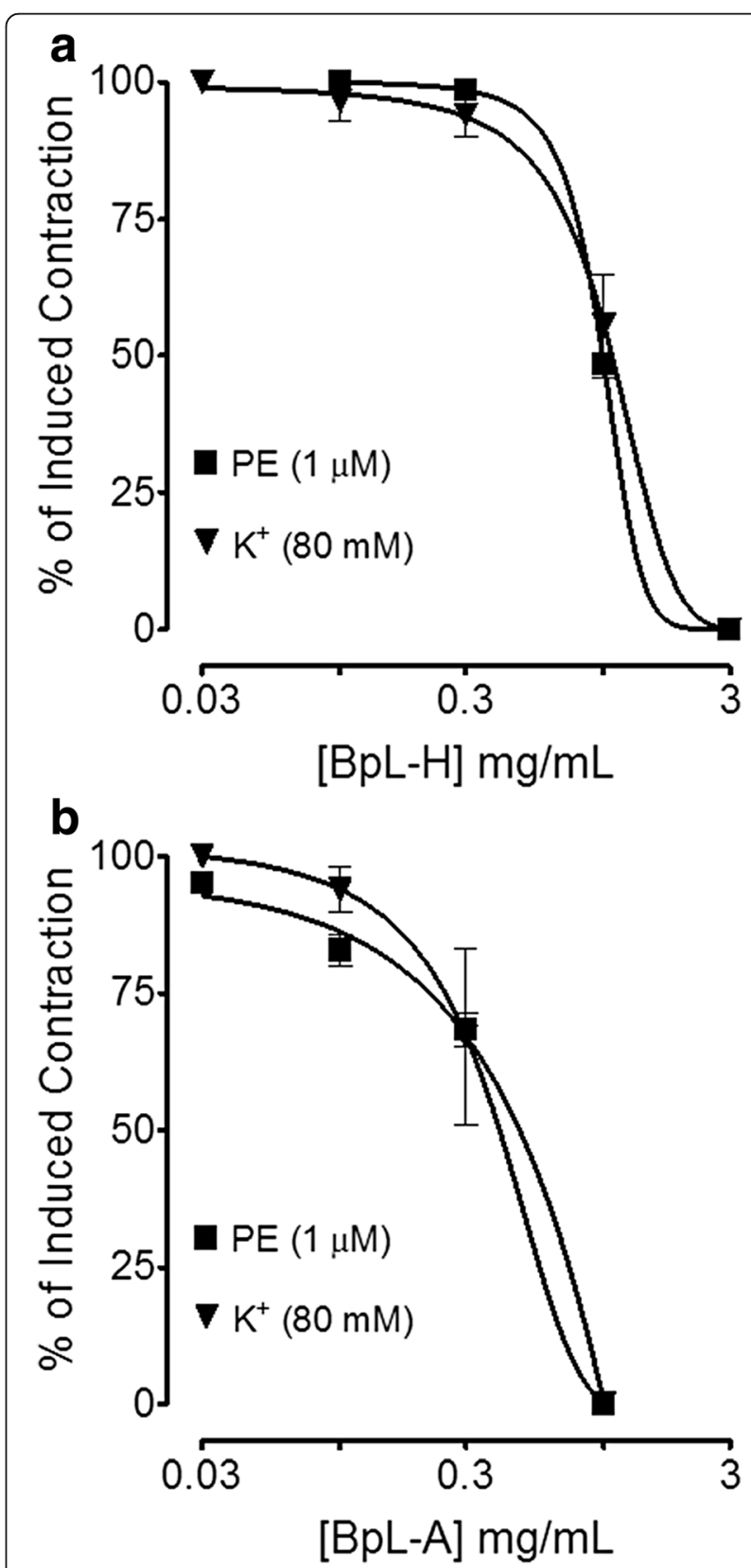

Fig. 9 Concentration-dependent inhibitory effect of Buxus papillosa leaves extract fractions: $\mathbf{a}$ hexane $(\mathrm{BpL}-\mathrm{H})$ and $\mathbf{b}$ aqueous $(\mathrm{BpL}-\mathrm{A})$ on phenylephrine (PE) and high $\mathrm{K}^{+}$-induced contractions in isolated rabbit aortic preparations. Values shown are mean $\pm \mathrm{SEM}, n=2-3$ 

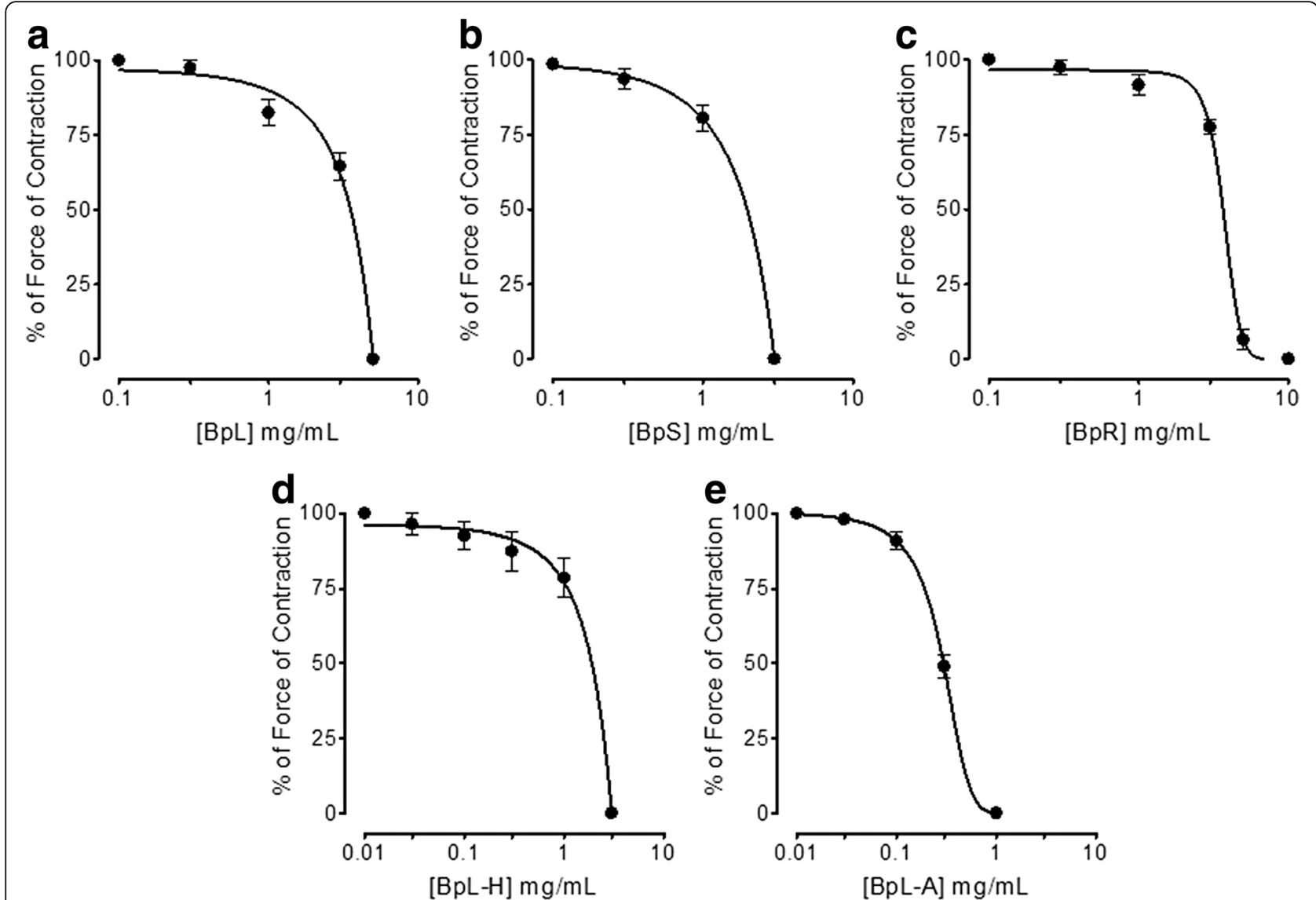

Fig. 10 Concentration-dependent inhibitory effect of Buxus papillosa different parts extracts: a leaves (BpL), b stem (BpS) and c roots (BpR) also leaves extract fractions: $\mathbf{d}$ hexane $(\mathrm{BpL}-\mathrm{H})$ and $\mathbf{e}$ aqueous (BpL-A) on force of contraction of the spontaneously beating isolated guinea-pig right atrial preparations. Values shown are mean $\pm \mathrm{SEM}, n=3$

ultimate result [53]. Non-specific inhibition of two spasmogens by the plant extract suggest nonspecific bronchodilatory effect, probably mediated through calcium channel blockade mechanism. For relieving symptoms of congestive respiratory disorders $\mathrm{Ca}^{++}$antagonists are efficient [54] and existence of CCB activity in Buxus papillosa as revealed by this study may provide basis for this plant as an effective agent for treating asthma.

The plant Buxuspapillosa was also studied in vascular and heart tissues for possible cardio-depressent and vasorelaxant actions, due to well known efficacy of $\mathrm{Ca}^{++}$antagonists in cardiovascular disorders, such as hypertension $[55,56]$. When applied on isolated aorta preparations, Buxus papillosa material inhibited contractions produced by high $\mathrm{K}^{+}$and PE. Vascular contraction is induced by PE via increase in cytosolic $\mathrm{Ca}^{++}$, to a degree because of $\mathrm{Ca}^{++}$ entry via receptor operated channels and up to some extent due to $\mathrm{Ca}^{++}$release from intracellular stores [57]. Non-specific inhibition of high $\mathrm{K}^{+}$and PE by the plant extract suggests nonspecific vasodilatory effect, probably mediated via CCB mechanism. The product of cardiac output and vascular resistance results blood pressure [58], so the likely inhibitory effect of this extract on heart was studied. Atrial force of contractions was inhibited by Buxus papillosa in spontaneously beating atria of guinea-peg.

Among all tested samples of the plant, aqueous fraction most potently caused cardiac depression, being 13 times more potent than parent extract. Cardiac inhibitory effect of Buxus papillosa, occurred possibly via CCB pathway (observed in gut, trachea and vascular tissues experiments), as $\mathrm{Ca}^{++}$antagonists reportedly possess negative inotropic and chronotropic effects [59]. All tested samples of Buxus papillosa (except aqueous fraction, which was about 10 times more potent in relaxing intestinal preparations than tracheal) were relatively more powerful spasmolytic in airways, in comparison to other targeted tissues, this might be due to heterogenicity of $\mathrm{Ca}^{++}$channels, as known to be heterogeneous $[60,61]$. Various types of $\mathrm{Ca}^{++}$channels blockers, for different organ system are reported to demonstrate selectivity [62, 63]. For instance, nifedipine reportedly is a vascular selective, as compared to heart [64]. On the other hand, there is also the possibility of phosphodiestarse inhibitors (PDEIs)-like constituent(s), which have impaired cardiac inhibitory potency. 
We have reported co-existence of PDEIs component(s) with $\mathrm{Ca}^{++}$antagonist(s) in some medicinal plants [65-68]. As, combination of PDEIs and $\mathrm{Ca}^{++}$antagonists have synergistic spasmolytic interaction in smooth muscles (more effective in respiratory system) and opposing/side effects neutralizing effects in heart [69], hence might making the plant more efficacious to relax airways, compared to cardiac muscles.

\section{Conclusions}

These results reveal that Buxus papillosa possesses antispasmodic, bronchodilatory, vasodilator and cardiac inhibitory effects. Thus, this study provides scientific evidence for its potential therapeutic application in hyperactive gastrointestinal, respiratory and cardiovascular disorders.

\section{Abbreviations}

ACh: Acetylcholine chloride; BpL: Buxuspapillosaleaves extract; BpLA: Buxuspapillosaleaves extract aqueous fraction; BpL-H: Buxuspapillosaleaves extract hexane fraction; BpR: Buxuspapillosaroot extract;

BpS: Buxuspapillosastem extract; CCB: Ca ${ }^{++}$channel blockade; CCh: Carbachol; KPK: Khyber Pakhtunkhwa; PDEls: Phosphodiestarse inhibitors; PE: Phenylephrine hydrochloride; VDCs: Voltage dependent L-type $\mathrm{Ca}^{++}$ channels

\section{Acknowledgements}

We want to extend our thanks and appreciation to Dr. Atlas Khan Marwat for helping in the plant collection.

\section{Funding}

This study was supported by the grant from Pakistan Science Foundation.

\section{Availability of data and materials}

All relevant materials and data is present in the paper.

\section{Authors' contributions}

AK performed experiments, collected data, evaluated data and conducted literature review along with preparation of final manuscript. SA, MA and MIC helped in plant collection, identification and extraction. AHG supervised the whole research work and arranged funds, refined manuscript for final publication. Final manuscript, after reading, has been approved by all authors for publication.

\section{Competing interests}

The authors declare that they have no competing interests.

\section{Consent for publication}

Not applicable.

\section{Ethics approval and consent to participate}

Experimental work conducted here completely comply with ruling of the Institute of Laboratory Animal Resources, Commission on Life Sciences, National Research Council (1996), approved by Research and Ethics Committee (Ref\#: REC/RIPS/2016/005), Riphah Institute of Pharmaceutical Sciences.

\section{Author details}

'Department of Pharmacology, Riphah Institute of Pharmaceutical Sciences, Riphah International University, Islamabad, Pakistan. ${ }^{2}$ Molecular and Integrative Physiological Sciences, Harvard School of Public Health, Boston, MA, USA. ${ }^{3}$ Department of Biological and Biomedical Sciences, The Aga Khan University Medical College, Karachi 74800, Pakistan. ${ }^{4}$ Pakistan Council of Science and Technology, Islamabad, Pakistan. ${ }^{5}$ Department of Chemistry, University of Malakand, Chakdara, Dir (L), Pakistan. ${ }^{6}$ International Center for Chemical and Biological Sciences, H EJ Research Institute of Chemistry, University of Karachi, Karachi, Pakistan.
Received: 5 May 2016 Accepted: 5 January 2017

Published online: 18 January 2017

\section{References}

1. Din HK, Lodhi HMA. Kitabul Mufradat. Lahore: Mukataba Dinyal; 1990.

2. Shamma M, Georgiev VS, Miana GA, Khan FS. Three new alkaloids from Buxus papillosa. Phytochemistry. 1973;12(8):2051-4.

3. Atta-ur-Rahman, Nisa M. The isolation and structure of "harappamine" a new alkaloid from Buxus papillosa. Heterocycles. 1983;20(1):69-70.

4. Atta-ur-Rahman, Nisa M, Farhi S. Isolation of moenjodaramine from Buxus papillosa. Planta Med. 1983:49(10):126.

5. Atta-ur-Rahman, Nisa M, Zamir T. The isolation and structure of papilicine, a new alkaloid from Buxus papillosa. Z Naturforsch. 1984;39B(1):127-8.

6. Atta-ur-Rahman, Nisa M, Jahan K. Isolation and structure of buxaminol-G, an alkaloid from Buxus papillosa. Phytochemistry. 1985;24(6):1398-9.

7. Atta-ur-Rahman, Farhi S, Miana GA, Nisa M. The isolation and structure of papilamine, a new alkaloid from Buxus papillosa. Z Naturforsch. 1985;40B(4): $567-8$

8. Atta-ur-Rahman, Nisa M, Zamir T, Volter W. The isolation and structure of papilinie. A new alkaloid from Buxus papillosa. Z Naturforsch. 1985;40B(4): 565-6.

9. Choudhary MI, Atta-ur-Rahman, Freyer AJ, Shamma M. Five new steroidal alkaloids from Buxus papillosa. Some relationships between structures and specific rotations. Tetrahedron. 1986;42(20):5747-52.

10. Atta-ur-Rahman, Alam M, Choudhary Ml, Firdous S. NFormylcyclomicrobuxeine-A new alkaloid from the leaves of Buxus papillosa. Planta Med. 1987;53(5):496-7.

11. Choudhary MI, Freyer AJ, Shamma M. New alkaloids from Buxus papilosa. J Nat Prod. 1987;50(1):84-8.

12. Atta-ur-Rahman, Alam M, Choudhary MI. (+)-N-Acetyl-Ndemethylcyclomicrobuxeine isolation, structure and conformational studies. Phytochemistry. 1988;27(10):3342-3.

13. Atta-ur-Rahman, Alam M, Choudhary MI. Buxaminone-A new alkaloid from leaves of Buxus papillosa. J Nat Prod. 1988:51(2):309-10.

14. Choudhary Ml, Atta-ur-Rahman, Shamma M. Four steroidal alkaloids from Buxus papillosa. Phytochemistry. 1988;27(1):271-4.

15. Choudhary MI, Atta-ur-Rahman, Shamma M. (+)-formylharappamine and (+)-N-formylpapalicine. Two new alkaloid from Buxus papillosa. Phytochemistry. 1988;27(5):1561-2.

16. Atta-ur-Rahman, lqbal Z, Nasir H, Chodhary MI, Alam M. Triterpenoids constitutents of Buxus papillosa. Phytochemistry. 1989:28(10):2848-50.

17. Atta-ur-Rahman, lqbal Z, Choudhary MI, Fatima T. Buxapapilinine-A novel alkaloid from the leaves of Buxus papillosa. Heterocycles. 1990;31(3):493-8.

18. Atta-ur-Rahman, Asif E, Ali S, Nasir H, Jamal SA, Ata A, Farooq A, Choudhary MI, Sener B, Turkoz S. New steroidal alkaloids from roots of Buxus papillosa. J Nat Prod. 1992;55(8):1063-6.

19. Atta-ur-Rahman, Nasir H, Ali S, labal Z. Buxapapillosin-A new triterpene from roots of Buxus papillosa. Nat Prod Lett. 1993;3(2):131-8.

20. Atta-ur-Rahman, Nasir H, lqbal Z. Two non- nitrogenous triterpenoids from roots of Buxus papillosa. Phytochemistry. 1994:35(4):993-1000.

21. Atta-ur-Rahman, Parveen S, Khalid A, Faroog A, Choudhary MI. Acetyl and butyrylcholinesterase-inhibiting triterpenoid alkaloids from Buxus papillosa. Phytochemistry. 2001;58(6):963-8

22. Sindhu ZU, Jonsson NN, labal Z. Syringe test (modified larval immersion test): a new bioassay for testing acaricidal activity of plant extracts against Rhipicephalus microplus. Vet Parasitol. 2012:188(3-4):362-7.

23. Gilani AH, Mandukhail SR, Iqbal J, Yasinzai M, Aziz N, Khan A, Rehman N. Antispasmodic and vasodilator activities of Morinda citrifolia root extract are mediated through blockade of voltage dependent calcium channels. BMC Complement Altern Med. 2010;10:2.

24. Chaudhary MA, Imran I, Bashir S, Mehmood MH, Rehman N, Gilani AH. Evaluation of gut modulatory and bronchodilator activities of Amaranthus spinosus Linn. BMC Complement Altern Med. 2012;12:166.

25. Khan A, Mustafa MR, Khan A, Morgan DD. Hypotensive effect of Gentiana floribunda is mediated through $\mathrm{Ca}^{++}$antagonism pathway. BMC Complement Altern Med. 2012;12:121

26. Aziz N, Mehmood MH, Gilani AH. Studies on two polyherbal formulations (ZPTO and ZTO) for comparison of their antidyslipidemic, antihypertensive and endothelial modulating activities. BMC Complement Altern Med. 2013; 13:371. 
27. Shareef H, Rizwani GH, Mandukhail SR, Watanabe N, Gilani AH. Mechanism underlying antidiarrhoeal, antispasmodic and bronchodilator activities of Ipomoea turpethum linn. BMC Complement Altern Med. 2014;14:479.

28. Alam N, Hossain M, Mottalib A, Sulaiman AS, Gan SH, Khalil MI. Methanolic extracts of Withania somnifera leaves, fruits and roots possess antioxidant properties and antibacterial activities. BMC Complement Altern Med. 2012;12:175.

29. Sajid Zl, Anwar F, Shabir G, Rasul G, Alkharfy KM, Gilani AH. Antioxidant, antimicrobial properties and phenolics of different solvent extracts from bark, leaves and seeds of Pongamia pinnata (L.) pierre. Molecules. 2012; 17(4):3917-32.

30. Nakano T, Terao S. Buxus alkaloids. IV. Isolation and structure elucidation of eight new alkaloids, cyclomicrophylline- $A,-B$, and $-C$, dihydrocyclomicrophylline-A and -F, cyclomicrophyllidine- $A$, dihydrocyclomicrophyllidine-A, and cyclomicrobuxine, from B. microphylla Sieb. et Zucc. var. suffruticosa Makino. J Chem Soc Perkis. 1965;1:4512-37.

31. Parvez M, Atta-ur-Rahman, Choudhary MI, Parveen S, Ayatollahi SA. Cyclomicrobuxine monohydrate. Acta Crystallogr C Struct Chem. 2000; 56(Pt 2):233-4.

32. Kuete V, Teponno RB, Mbaveng AT, Tapondjou LA, Meyer JJ, Barboni L, Lall N. Antibacterial activities of the extracts, fractions and compounds from Dioscorea bulbifera. BMC Complement Altern Med. 2012;12:228.

33. National Research Council. Guide for the care and use of laboratory animals. Washington: National Academy Press; 1996.

34. Khan A, Khan M, Subhan F, Gilani AH. Antispasmodic, bronchodilator and blood pressure lowering properties of Hypericum oblongifolium-possible mechanism of action. Phytother Res. 2010;24(7):1027-32.

35. Gilani SN, Khan A, Gilani AH. Pharmacological basis for the medicinal use of Zanthoxylum armatum in gut, airways and cardiovascular disorders. Phytother Res. 2010;24(4):553-8.

36. Gilani AH, Bashir S, Khan A. Pharmacological basis for the use of Borago officinalis in gastrointestinal, respiratory and cardiovascular disorders. J Ethnopharmacol. 2007;114(3):393-9.

37. Khan A, Gilani AH, Rehman N. Pharmacological studies on Hypericum perforatum fractions and constituents. Pharm Biol. 2011;49(1):46-56.

38. Khan A, Gilani AH. Cardiovascular inhibitory effects of Hyoscyamus niger. Methods Find Exp Clin Pharmacol. 2008;30(4):295-300.

39. Karaki H, Ozaki H, Hori M, Mitsui-Saito M, Amano K, Harada K, Miyamoto S, Nakazawa H, Won KJ, Sato K. Calcium movements, distribution, and functions in smooth muscle. Pharmacol Rev. 1997;49(2):157-230.

40. Grasa L, Rebollar E, Arruebo MP, Plaza MA, Murillo MD. The role of $\mathrm{Ca}^{+2}$ in the contractility of rabbit small intestine in-vitro. J Physiol Pharmacol. 2004 55(3):639-50.

41. Brading AF. How do drugs initiate contraction in smooth muscles. Trends Pharmacol Sci. 1981;2:261-5.

42. Gilani AH, Janbaz KH, Lateef A, Zaman M. Ca ${ }^{++}$channel blocking activity of Artemesia scoparia extract. Phytother Res. 1994;8(3):161-5.

43. Gilani AH, Jabeen Q, Ghayur MN, Janbaz KH, Akhtar MS. Studies on the antihypertensive, antispasmodic, bronchodilator and hepatoprotective activities of the Carum copticum seed extract. J Ethnopharmacol. 2005; 98(1-2):127-35.

44. Gilani AH, Shah AJ, Ghayur MN, Majeed K. Pharmacological basis for the use of turmeric in gastrointestinal and respiratory disorders. Life Sci. 2005;76(26): 3089-105.

45. Yaeesh S, Jamal Q, Khan A, Gilani AH. Studies on hepatoprotective, antispasmodic and calcium antagonist activities of the aqueous-methanol extract of Achillea millefolium. Phytother Res. 2006;20(7):546-51.

46. Khan H, Ali I, Khan AU, Naz R, Gilani AH. Antibacterial, antifungal, antispasmodic and $\mathrm{Ca}^{++}$antagonist activities of Caesalpinia bonducella. Nat Prod Res. 2012;25(4):444-9.

47. Fleckenstein A. Specific pharmacology of calcium in myocardium, cardiac pacemakers, and vascular smooth muscle. Ann Rev Pharmacol Toxicol. 1977; 17:149-66.

48. Bolton TB. Mechanisms of action of transmitters and other substances on smooth muscle. Physiol Rev. 1979;59(3):606-718.

49. Godfraind T, Miller R, Wibo M. Calcium antagonism and calcium entry blockade. Pharmacol Rev. 1986;38(4):321-416.

50. Farre AJ, Columbo M, Fort M, Gutierrez B. Differential effects of various $\mathrm{Ca}^{++}$ antagonists. Gen Pharmacol. 1991;22(1):177-81.

51. Triggle DJ. Drugs affecting calcium-regulation and actions. In: Smith GM, Reynard AM, editors. Textbook of Pharmacology. Philadelphia: WB Saunders Co; 1992. p. 453-79.
52. Reynolds IJ, Gould RJ, Snyder SH. Loperamide: blockade of calcium channels as a mechanism for antidiarrhoeal effects. J Pharmacol Exp Ther. 1984;231(3):628-32.

53. Rang HP, Dale MM, Ritter JM. Pharmacology. 4th ed. New York: Churchill Livingstone; 1999.

54. Mathewson HS. Anti-asthmatic properties of calcium antagonists. Respir Care. 1985;30:779-81.

55. Ghayur MN, Gilani AH. Ginger lowers blood pressure through blockade of voltage-dependent calcium channels. J Cardiovasc Pharmacol. 2005;45(1):74-80.

56. Epstein M. Calcium antagonists in the management of hypertension. In: Epstein $M$, editor. Calcium antagonists in clinical medicine. Philadelphia: Hanley and Belfus Inc; 1992. p. 213-30.

57. Graham RM, Perez DM, Hwa J, Piascik MT. $a_{1}$-adrenergic receptor subtypes, molecular structure, function and signaling. Circ Res. 1996;78(5):737-49.

58. Johansen PL. Hemodynamic effects of calcium antagonists in hypertension. In: Epstein $\mathrm{M}$, editor. Calcium antagonists in clinical medicine. Philadelphia: Hanley and Belfus Inc; 1992. p. 69-88.

59. Billman GE. The antiarrythmic effects of the calcium antagonists. In: Epstein $M$, editor. Calcium antagonists in clinical medicine. Philadelphia: Hanley and Belfus Inc; 1992. p. 183-212.

60. Hess P, Lansman JB, Tsien RW. Different modes of $\mathrm{Ca}^{++}$channel gating behavior favored by dihydropyridines $\mathrm{Ca}^{++}$agonists and antagonists. Nature. 1984;311(5986):538-44.

61. Tsien RW, Ellinor PT, Horne A. Molecular diversity of voltage-dependent $\mathrm{Ca}^{+}$ + channels. Trends Pharmacol Sci. 1991;12(9):349-54.

62. Polster P, Christophe M, Damme V, Houlliche A, Chatelain P. SR33557, a novel calcium entry blocker.1. In vitro isolated tissue studies. J Pharmacol Exp Ther. 1990;255(2):593-9.

63. Godfraind T, Salomone S, Dessy C, Verhelst B, Dion R, Schoevaerts JC. Selectivity scale of calcium antagonists in the human cardiovascular system based on in-vitro studies. J Cardiovasc Pharmacol. 1992;20 Suppl 5:S34-41.

64. Wadsworth RM. Selectivity of calcium antagonist drugs on vascular smooth muscle. Clin Exp Pharmacol Physiol. 1993;20(12):745-51.

65. Gilani AH, Khan A, Subhan F, Khan M. Antispasmodic and bronchodilator activities of St. John's wort are putatively mediated through dual inhibition of calcium influx and phosphodiesterase. Fundam Clin Pharmacol. 2005; 19(6):695-705

66. Khan M, Khan A, Rehman N, Gilani AH. Pharmacological explanation for the use of Juniperus excelsa in hyperactive gastrointestinal and respiratory disorders. J Nat Med. 2012;66(2):292-301.

67. Khan M, Khan A, Rehman N, Gilani AH. Gut and airways relaxant effects of Carum roxburghianum. J Ethnopharmacol. 2012;141(3):938-46.

68. Rehman N, Khan A, Alkharfy KM, Gilani AH. Pharmacological basis for the medicinal use of Lepidium sativum in airways disorders. Evid Based Complement Alternat Med. 2012;ID 596524:8.

69. Khan A, Gilani AH. Natural products useful in respiratory disorders: focus on side-effects neutralizing combinations. Phytother Res. 2015;29(9):1265-85.

\section{Submit your next manuscript to BioMed Central and we will help you at every step:}

- We accept pre-submission inquiries

- Our selector tool helps you to find the most relevant journal

- We provide round the clock customer support

- Convenient online submission

- Thorough peer review

- Inclusion in PubMed and all major indexing services

- Maximum visibility for your research

Submit your manuscript at www.biomedcentral.com/submit
C Biomed Central 